\title{
Compressive Strength of Permeable Asphalt Pavement Using Domato Stone (Quarzite Dolomite) and Buton Natural Asphalt (BNA) Blend
}

\author{
Firdaus Chairuddin, M. Wihardi Tjaronge, Muhammad Ramli, and Johannes Patanduk
}

\begin{abstract}
This research aims to study the usability of domato stone as coarse aggregate in mixure of permeable asphalt pavement. This study focuses to examine the compressive strength and the stress strain relationship of permeable asphalt containing domato stone and BNA (Buton Natural Asphalt) Blend. Domato stone is a limestone containing quarzite dolomite that obtained from the coast of the Banggai island, Central Celebes. The test results shows that the stress strain curve of compression test results for dense asphalt concrete was similar to the stress strain curve of the porous asphalt using domato stone and BNA blend.The unconfined compressive test result of porous asphalt containing domato stone showed that the mixture with $4 \%$ BNA has compressive strength value $2.4 \mathrm{MPa}$ and void ratio $19.2 \%$, respectively.
\end{abstract}

Index Terms-Permeable asphal pavement, domato stone, buton natural asphalt (BNA) blend, stress strain curve, compressive strength.

\section{INTRODUCTION}

The natural rock asphalt is a sedimentary rock containing of high hydrocarbon substances. The natural rock asphalt with deposit of approximately 60,991,554.38 ton $(24,352,833.07$ barrel oil equivalent) occurs in the southern area of Buton Island, Indonesia [1]. Buton natural asphalt (BNA) blend is a type of modification asphalt which is made of $75 \%$ Petroleum asphalt $60 / 70$ and $25 \%$ rock asphalt Buton Natural extraction [2].

The rapid growth of national economic in recent years resulted in a lot of transportation infrastructure demand. Approximately 600,000 tons of petroleum bitumen must be imported annually to fulfill the maintenances and construction of new road demand. The utilization of BNA blend for the road development increases the national asphalt industry growth. Many islands in Indonesia possess lime stones resources that can be used as coarse aggregate. Domato stone is a local name of lime stone (quarzite dolomite) that can be found in around of Banggai Laut area, Indonesia. In order to produce permeable asphalt, F. Chairuddin et al., (2014) employed domato stone and BNA blend as coarse aggregate and bituminous material, respectively. The results of porosity test, permeability test, stability test, flow test, indirect tensile test and material loss test (Cantabro test) showed the bonding strength between BNA blend and domato stones can be established thus can

Manuscript received July 12, 2014; revised December 23, 2014.

The authors are with the Civil Enginering Department, Hasanuddin University, Indonesia (e-mail: firdauschairuddin@gmail.com, tjaronge@yahoo.co.jp, patandukjohannes@yahoo.ac.id) enhanced the resistance of porous asphalt against raveling, rutting and shoving [2].

The water ponding on the road surface is caused by the heavy precipitation of high intensity rain fall. The water ponding problem during the rainy condition can be decreased by the employment of the permeable asphalt (porous asphalt) as a surfacing road pavement [3]-[5].

The solid that is subjected to the short time load are fundamentally characterized by the parameters of stress-strain curve. The failure of asphalt concrete specimens, the behavior of asphalt concrete under load as degeneration of the material and the limit of elasticity can be described by the stress-strain relationship for asphalt concrete in compression [6]. The unconfined compressive test combined with the indirect strength test can be used to calculate the cohesion strength and the angle of internal strength of the porous asphalt [7].

This work is a part of various extensive investigation projects on the development of liquid Asbuton as bituminous asphalt binder and the suitability of domato stone as coarse aggregate in the permeable asphalt production. This paper reported the test results those are carried out to study the compressive strength and the stress strain curve in compression of the permeable asphalt.

\section{MATERIALS AND EXPERIMENTAL METHODS}

\section{A. Rheological Properties of BNA Blend}

Table I shows the rheological properties of BNA blend. Penetration value of 54 (unit: $0.1 \mathrm{~mm}$ ) shows that BNA blend was slightly harder than the pure petroleum bitumen with $60 / 70$ penetration grade.

TABLE I: TeSting Methods FOR RHEOLOGICAL PROPERTIES OF BNA BLEND

\begin{tabular}{|c|c|c|}
\hline \\
\hline Properties & Value & Unit \\
\hline Penetration at $25^{\circ} \mathrm{C}$ & 54 & $0.1 \mathrm{~mm}$ \\
\hline Softening Point & 57.25 & ${ }^{\circ} \mathrm{C}$ \\
\hline Ductility & 150 & $\mathrm{Cm}$ \\
\hline Flash Point & 305 & ${ }^{\circ} \mathrm{C}$ \\
\hline Density & 1.0445 & \\
\hline Loss on Heating TFOT & 1.41 & $\% \mathrm{wt}$ \\
\hline Penetration after loss on heating & 79.3 & $\%$ \\
\hline Viscosity 135 Cst ( Temp. mixing) & 1826 & ${ }^{\circ} \mathrm{C}$ \\
\hline
\end{tabular}

\section{B. Physical Properties of Aggregates}

The physical properties of aggregates are shown in Table II. This research utilized the open graded of crushed domato stone and the river sand as coarse aggregate and as fine aggregate, respectively. A small amount of sand was added to form a matrix that controls the cohesiveness and flow of 
mixture.

TABLE II: PHYSICAL PROPERTIES OF AGGREGATES

\begin{tabular}{lcc}
\hline \multicolumn{1}{c}{ Properties } & Crushed domato stone & Sand \\
\hline Specific Gravity & & \\
a. Bulk / Dry & 2.51 & 2.51 \\
b. Surface Saturated Dry & 2.56 & 2.52 \\
c. Apparent & 2.64 & 2.71 \\
Abrasion (\%) & 33.52 & - \\
Flanknes (\%) & 9.23 & - \\
Sand Equivalent (\%) & - & 85.71 \\
Absorption (\%) & 1.9 & 2.7 \\
\hline \hline
\end{tabular}

\section{Mixture of Porous Asphalt}

There were some trial mixes and the preliminary tests were conducted to gain the composition of porous asphalt (F. Chairuddin et al., 2013). Contain of BNA blend was varied from $3 \%$ to $5 \%$ by weight of porous asphalt mixture, at $0.5 \%$ interval. Porous asphalt was designed with porosity of $17.25 \pm 2.5 \%$. The composition of the coarse aggregate and fine aggregate are $90 \%$ and $10 \%$, respectively. Where coarse aggregate consisting of crushed domato stone with diameter of $3 / 8$ " and 1/2" are 50\% and 50\%, respectively. The standard Marshall mold with capacity of the 1,200g sample was used to prepare the specimens. All specimens were compacted with a Marshall compactor using $2 \times 50$ blows, as shown in Fig. 1.

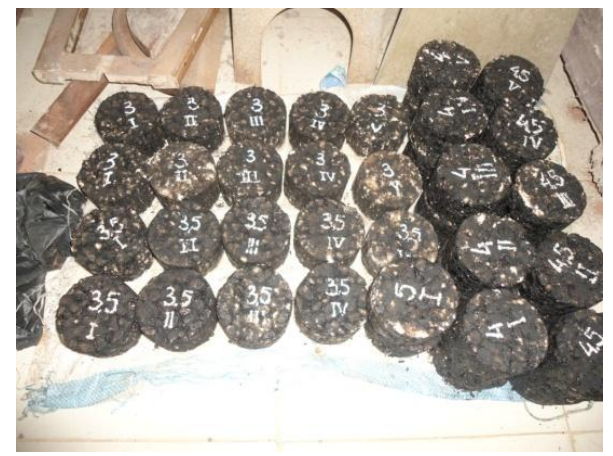

Fig. 1. Porous asphalt specimens.

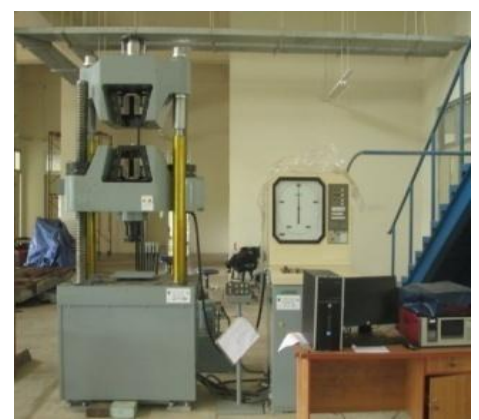

Fig. 2. Equipment of compressive strength test.

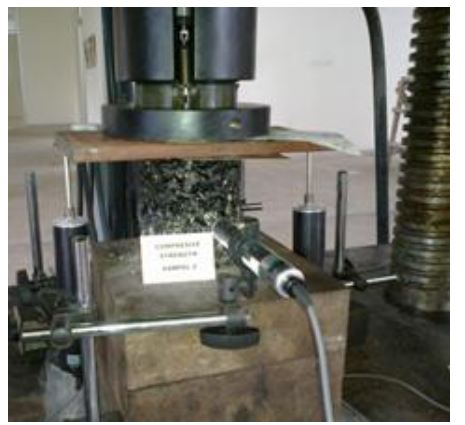

Fig. 3. Unconfined compressive strength test with LVDT.

\section{Compresivve Strengh Test}

Compressive strength test are shown in Fig. 2 and Fig. 3. The axial and lateral deformations were measured with LVDT as shown in Fig. 3.

\section{RESUlTS AND DisCUSSION}

There are two configurations of stress strain curve were seen in all mixtures irrespective of the BNA blend content. The first configuration shows some porous asphalt specimens have the initial bottom concave part that represents the settling of the specimen, the linear zone, the nonlinear zone of the ascending branch and comprises the peak and stretch immediately adjoining it on other side. This pattern is similar to the pattern of the dense asphalt concrete. The second configuration shows some porous asphalt specimens have the linear zone, the nonlinear zone of the ascending branch and comprises the peak and stretch immediately adjoining it on other side without the initial bottom concave part. This pattern slightly differs to the pattern of the dense asphalt concrete. The nonlinear part of stress strain curve of porous asphalt reflects the degeneration of the later rather than the flow of very thin bitumen micro layers in it. Micro cracking process characterizes the nonlinear part of the ascending branch. The elastic behavior is reflected by the linear part of the stress strain curve. Under the short term static compressive, all test showed no significant change in the peak strain with increasing compressive strength of porous asphalt. According to S.Stardubski et al., (1994) the peak strain changes on average from 19 mill strain (0.0019) to 22 $(0.0022)$ or 23 mill strain $(0.0023)$ in the compressive strength of dense asphalt concrete with interval of $1.6 \mathrm{MPa}$ $-5.4 \mathrm{MPa}$. As the strength of permeable asphalt increases from $1.2 \mathrm{MPa}$ to $2.4 \mathrm{MPa}$, the range of its peak strain is average from 0.001 to 0.005 , which is relatively similar to the peak strain of dense asphalt concrete.

WU Shao Peng et al., (2006) employed asphalt butadiene styrene polymer (SBS) modified asphalt with performance grade PG76-22, crushed basalt aggregate and limestone to produce porous asphalt. Unconfined compression test was run using $100 \mathrm{~mm}$ by 100 core drilled. At $4.5 \%$ asphalt content, unconfined compressive strength and void ratio were $3601 \mathrm{kPa}(3.6 \mathrm{MPa})$ and approximated $21.1 \%$, respectively.

Fig. 4 shows the unconfined compresive strength result for $3 \%$ BNA Blend content. The stress strain relationship shows that at the average peak stress of $1.96 \mathrm{MPa}$ resulting in strain value of $0.031,0.031$, and 0.039 for three specimens, respectively.

Fig. 5 shows the unconfined compresive strength result for 3,5 \% BNA Blend content. The stress strain relationship shows that at the average peak stress of $1.93 \mathrm{MPa}$ resulting in strain value of $0.005,0.014$, and 0.017 for three specimens, respectively.

Fig. 6 shows the unconfined compresive strength result for $4 \%$ BNA Blend content. The stress strain relationship shows that at the average peak stress of $2.05 \mathrm{MPa}$ resulting in strain value of $0.021,0.025$, and 0.030 for three specimens , respectively.

Fig. 7 shows the unconfined compresive strength result for 4,5 \% BNA Blend content. The stress strain relationship shows that at the average peak stress of $2.05 \mathrm{MPa}$ resulting in 
strain value of $0.04,0.011$, and 0.012 for three specimens, respectively.

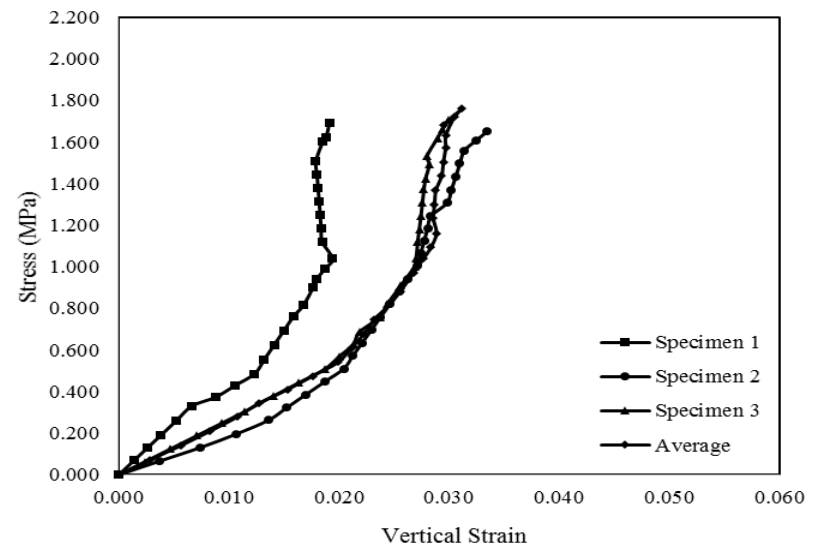

Fig. 4. Stress strain curve (BNA blend content 3\%).

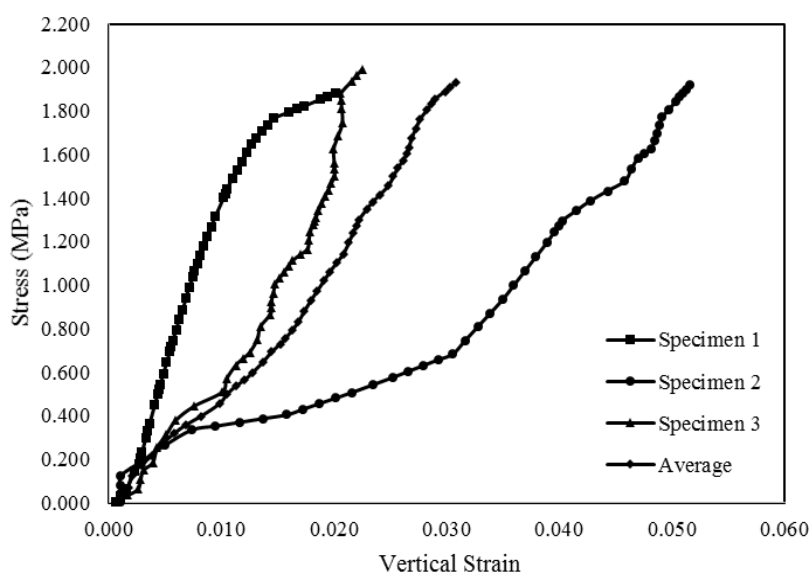

Fig. 5. Stress strain curve (BNA blend content 3,5\%).

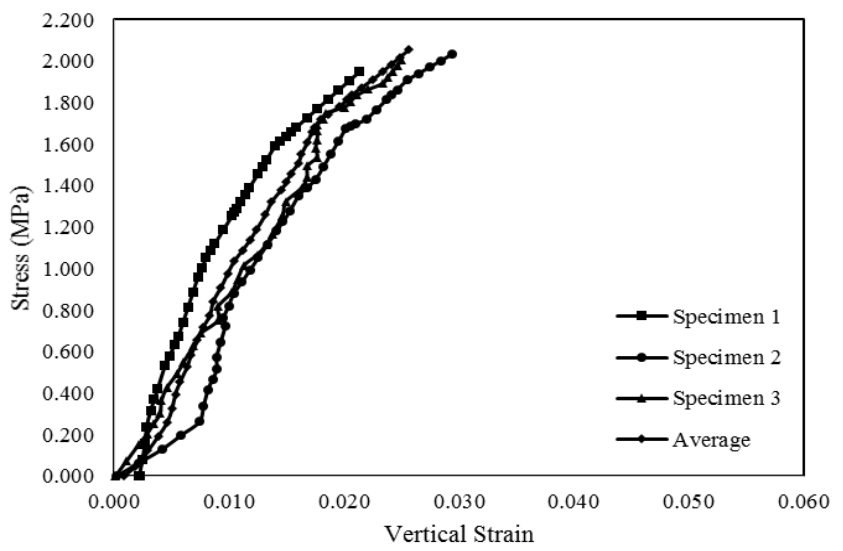

Fig. 6. Stress strain curve (BNA blend content 4\%).

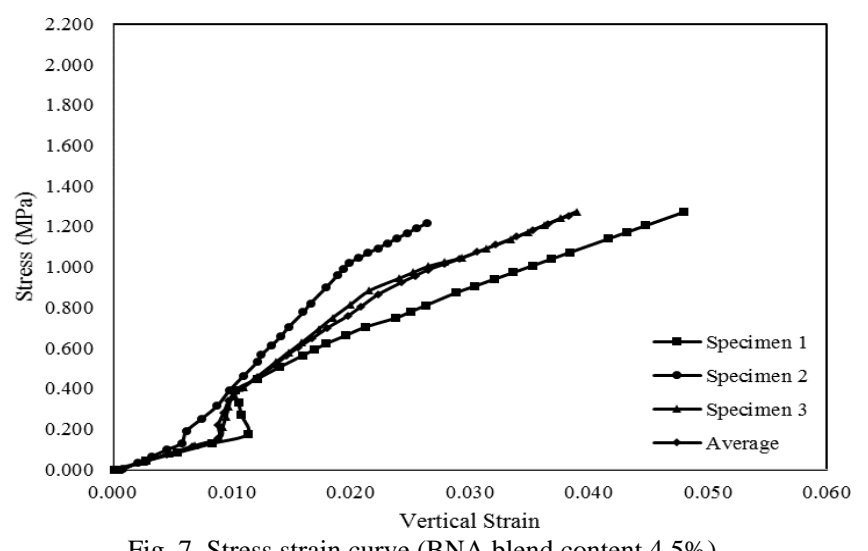

Fig. 7. Stress strain curve (BNA blend content $4,5 \%$ ).

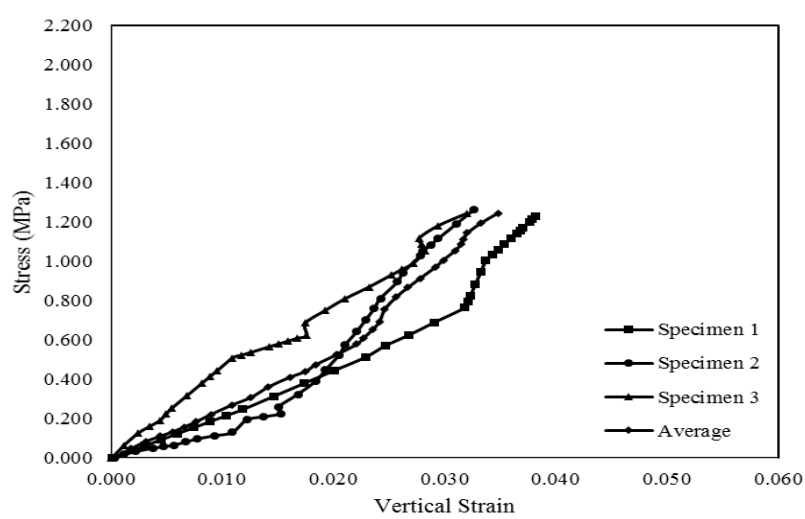

Fig. 8. Stress strain curve (BNA blend content 5\%).

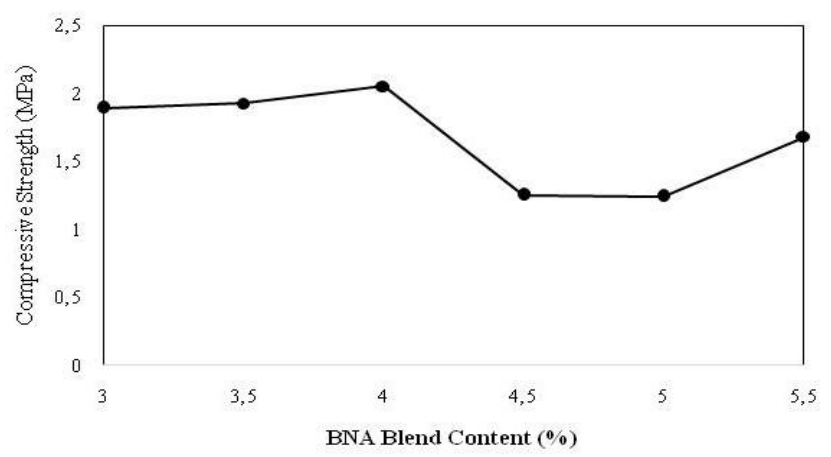

Fig. 9. Stress strain curve (BNA blend content 5.5\%).

Fig. 8 shows the unconfined compresive strength result for $5 \%$ BNA Blend content. The stress strain relationship shows that at the average peak stress of 1.24 MPa resulting in strain value of 0.0310 .031 , and 0.039 for three specimens, respectively.

Fig. 9 shows that the unconfined compressive test result of porous asphalt containing domato stone showed that the mixture with $4 \%$ BNA has compressive strength value 2.4 $\mathrm{MPa}$ and void ratio $19.2 \%$, respectively.

\section{CONCLUSION}

Stress strain curve of compression test results for asphalt concrete was same with stress strain curve of the porous asphalt using Domato stone and BNA blend.

Void ratio of porous asphalt tested by WU Shao-peng relatively similar to the porous asphalt using Domato stone and BNA blend, although the compressive strength according to $\mathrm{Wu}$ Shao-peng obtained at 3.6 $\mathrm{MPa}$ while the porous asphalt using Domato stone and BNA blend gained compressive strength of 2.4 MPa.

The unconfined compressive test result of porous asphalt containing domato stone showed that the mixture with $4 \%$ BNA has compressive strength value $2.4 \mathrm{MPa}$ and void ratio $19.2 \%$, respectively.

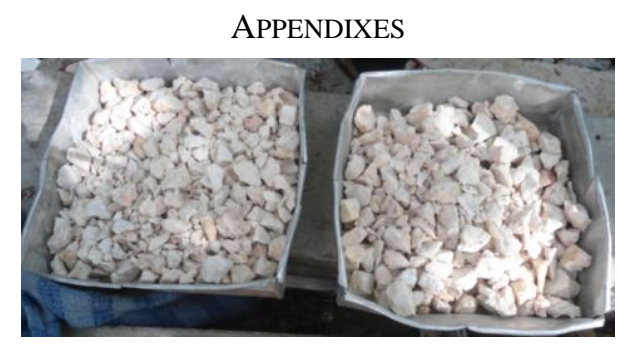

Appendix 1. Crushed domato stones. 


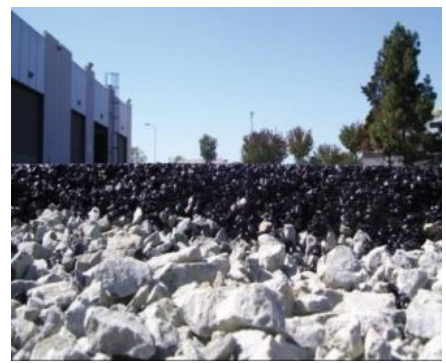

Appendix 2. Domato stones in natural condition used subgrade coarse aggregate.

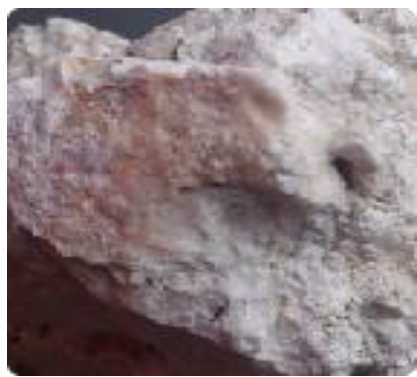

Appendix 3. Domato stones in natural condition.

\section{ACKNOWLEDGMENT}

Authors want to acknowledge the Indonesia Ministry of National Education, Directorate General of Higher Education on Doctoral Research Grants.

\section{REFERENCES}

[1] A. Suryana, "Inventory on solid bitumen sediment using 'outcrop drilling' in southern buton region, buton regency, province southeast sulawesi, colloquium on results activities of mineral resources inventory," Directorate Mineral Resources Inventory, Bandung, Indonesian, 2013.

[2] F. Chairuddin, M. W. Tjaronge, M. Ramli, and J. Patanduk, "Experimental study on permeable asphalt pavement used domato stone (quartzite dolomite) as coarse agregate for surface layer of road pavement," Advance Material Research, vol. 935, pp. 255-258, 2014.

[3] F. Hanim, A. Kamar, and J. N. Sarif, "Design of porous asphalt mixture to performance related criteria," in Proc. the $13^{\text {th }}$ Conference of the
Road Engineering Association of Asia and Australasia, Sidney, pp. 7-9, 2009.

[4] K. Nishijima, S. Higashi, and M. Ikeuchi, "Development of re-paved porous asphalt pavement method for reconstructing existing dense graded asphalt pavement into porous asphalt pavement using the in-place surface recycling method," in Proc. the 13th Conference of the Road Engineering Association of Asia and Australasia, Sidney: pp.5-14, 2009.

[5] M. Miradi, A. A. A. Moleenar, and M. F. C. V. D. Ven, "Performance modeling of porous asphalt concrete using artificial intelligence," Road Materials and Pavement Design, 2009, pp. 263-280.

[6] S. Starodusbsky, I Blechman, and M. Livneh. "Stress-strain relationship for asphalt concrete in compression," Material and Structures, vol. 27, pp. 474-482, 1994.

[7] S. P. Wu, G. Liu, L. T. Mo, Z. Chen, and Q. S. Ye, Effect of Fiber types on Relevant Properties of Porous Asphalt Transaction of Nonferrous Metals Society of China, 2006.

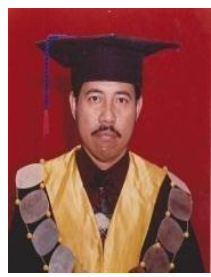

Firdaus Chairuddin is a doctor. He used to be a programmer at the Civil Engineering Department, Hasanuddin University, Indonesia during 1990-1996. He was working as the dean at the Engineering Faculty of 45 Makassar University, South Celebes during 1996-2000, He was working as the dean at Engineering Faculty, UKIT Tomohon, North Celebes during 2000-2004, and a deputy team leader of Gosowong Halmahera Mineral Oil Pubricant at Maluku during 2004-2011. He is a lecturer of Road Pavement at Atmajaya University during 2011-2014. He is now the doctor of civil engineering and a programmer studying S3 Pascasarjana, Hasanuddin University, Makassar, South Celebes.

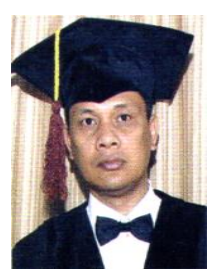

Muhammad Wihardi Tjaronge was born in Makassar, South Celebes in 1968. Now he is a professor and concentrates in the field of concrete construction materials at the Department of Civil Engineering, Faculty of Engineering, University of Hasanuddin, Makassar Indonesia. He received his bachelor of engineering degree (ST) at the University of Hasanuddin, Makassar in 1993. He received his master of engineering (M.Eng.) at the Nagoya Institute of Technology, Japan, in 1999, and he obtained the doctor of engineering (Dr. Eng.) at Nagoya Institute of Technology, Japan in 2002. 